\title{
Effect of the Freezing Point of Raw Milk on the Protein Content and Rheology of the Curd, Obtained by Combining Acid and Rennet Coagulation
}

\author{
Achraf Bouisfi \\ Ph.D. student \\ University Moulay Ismail Meknes \\ Faculty of Sciences \\ Morocco \\ Mohamed Chaoui \\ Professor \\ University Moulay Ismail Meknes \\ Faculty of Sciences \\ Morocco
}

Several studies have reported that the protein content of raw milk improves the curd characteristics, particularly the viscosity [1], it is the idea that does not cancel the influence of other parameters able to affect curd rheology [2,3]. The curd as a biocomposite, as in major load-bearing biocomposite, implants initial mechanical properties degraded by the presence of matrix porosity [4]. The objective of the current study was to assess how the freezing point of raw milk affects the rheological properties of combined acid and rennet induced gels.

Thirty experiments were conducted using fresh milk samples. These samples were collected during the spring period from six farms in the region of GHARB in Morocco, the farms are selected for their technical breeding. The objective is to reduce the effects of feeding, race and climate.

The freezing point of raw milk has a significant correlation with the curd characteristics. These findings can be exploited to optimize the raw milk control in order to obtain a curd with higher rheology quality.

Keywords : Raw milk, cows, curd, composition, rheology, freezing point

\section{INTRODUCTION}

Consumer acceptance of popular products such as yoghurts is highly dependent on their texture properties [1-5-6-7]; combined acid and rennet gelation is often used in the manufacture of certain types of cheese to improve gel firmness [8].

The aim of this current article is to study the possible correlations between the characteristics of raw milk and the curd texture, obtained by combined acidand rennet coagulation. Pearson correlation analysis was carried out to study the factors influencing curd characteristics (rheology and protein content), and to estimate the curd rheology for different rennet coagulation.

The physical characteristics, including viscosity and plasticity of rheological material are strongly dependent on their microscopic and macroscopic structures, as well as the presence of intermolecular forces [9]. Texture is the primary quality attribute of cheeses. The overall appearance and mouthfeel of cheeses are appreciated before their flavor. Major structure-forming component of cheese is the casein matrix in which fatty globules are entrapped; the serum is bound to casein and fills interstices of the matrix [10-11]. This network structure is critically affected by the relative content of protein, fat and water, as well as by the biochemical activities that occur almost continually during storage.

The characteristics of ripened cheese depend on both

Received: February 2018, Accepted: May 2018

Correspondence to: Achraf Bouisfi, Ph.D. student

University Moulay Ismail Meknes, Faculty of

Sciences, Morocco

E-mail: achraf.bouisfi@gmail.com

doi:10.5937/fmet1804644B

(C) Faculty of Mechanical Engineering, Belgrade. All rights reserved the manufacturing technology and the physico-chemical composition of the milk [12]. The strong interrelationship between food structure and texture is well known [13]. Based on spectroscopic data, Mazerolles noted that cheese texture is a reflection of its structure at the molecular level, the variability of physicochemical and sensory characteristics was important [14]; C. Agabriel studies were done during the winter period [12], but our study has been done on cheese production during the spring and summer period, exactly the period between March and June, knowing that large variations are often observed in cheese quality during these periods [15-16].

The raw milk used for this study is from six farms, because of their mastery of milk production technology, which is intended mainly for cheese production, they were involved in feeding practices, herd management (residential and cleanliness of dairy cows, practice of trafficking and calving distribution). A daily delivery of the milk is stored in a special tank for cheese making, all of them are in the plain which is in the GHARB region (the northwest of Morocco), that covers a total geographical area of 616,000 hectares with 388,000 hectares of agricultural area. The climate is Mediterranean with oceanic influence. The east-west rainfall gradient varies from 450 to $530 \mathrm{~mm}$, of which $80 \%$ is concentrated between 15 October and 15 April. The rest of the year is characterized by almost total lack of rainfall.

All cows are from Montbeliard breed with the same feeding regime; in spring, the fresh herbs of pasture are the main daily feed; these are mainly of green fodder $(5$ farms). In addition to this, the cows in the sixth farm are fed with hay, supplemented with grass silage. This is justified by the experimental results that were already 
obtained by Verdier [17-18], which shows that the method of forage conservation has a limited effect on the characteristics of the cheese when it is well controlled. This choice was made to focus more on the combined effect due to the freezing point and protein content of raw milk.

The driving skimming, fermentation and separation curd-whey are conducted with the same parameters. In this study, we want to explain the variability of the curd rheology in the same conditions of the production, based on the analysis of the protein content and freezing point of milk in all stages of the production process.

\section{MATERIALS AND METHODS}

The Kjeldahl method has been the official worldwide standard for the determination of nitrogen in all kinds of food and beverage samples. The Kjeldahl digestion converts nitrogen compounds (proteins, amines, orga-nic compounds) into ammonia compounds. Free ammonia is released by the addition of caustics, which are then expulsed by distillation and subsequently titrated. Total Kjeldahl nitrogen or TKN is often used as a surrogate for the protein content in milk samples. The factor conversion from TKN to protein is 6,38 [19]. The freezing point is an indirect measure of the osmotic pressure [20], measured by thermistor cryoscope, using a cryoscopy method (ISO/DIS 5764). The measures of freezing temperatures are given in absolute value (in $\left|\mathrm{m}^{\circ} \mathrm{C}\right|$ ). All these physicochemical analyses were measured for three representative samples of each delivery of raw milk. The freezing point of raw milk is slightly lower than that of water, because the presence of dissolved solids lowers the freezing point. It can range from $-0.53^{\circ} \mathrm{C}$ to $-0.575^{\circ} \mathrm{C}$ with an average of $-0.555{ }^{\circ} \mathrm{C}$ [21].

After skimming, the protein content of the skim milk is checked, the fermentation is carried out by mixed coagulation under the action of lactic acid bacteria and rennet proportion. Milk can be acidified by bacterial cultures, which ferment lactose to lactic acid [22]. Renneting is an early step of the cheese making process where rennet is added to milk, and the rennet enzymes coagulate the milk into a solid curd and whey [23]. The rennet concentrations were $0.0017 \%$, not far from $0,0025 \%$ already chosen [3], and $0,1 \mathrm{~g}$ of calcium solution per liter of skim milk. However, the mixed coagulation resulting from the combined action of coagulating enzymes and acidification by lactic bacteria has been less investigated [24-25].

The enzyme chymosin (the principal active agent in rennet) cleaves $\kappa-\mathrm{CN}$ at the surface of casein micelles, which reduces the net negative charge and steric repulsion between micelles, destabilizing them sufficiently to allow coagulation [26]. Rennet-hydrolyzed micelles thus become susceptible to aggregation, and a 3-dimensional gel network is formed [27].

The curd is drained to separate the whey from the curd; in this step, most of the soluble elements are removed to the whey. As the degree of draining determines the amount of water remaining in the curd, this step has a great influence on the final texture of the cheese. The draining degree varies depending on the gel contraction capacity, which determines its porosity.
Thus, if the gel shrinks slightly due to a lack of cohesion of the casein micelles, it will follow high porosity leading to an increase in water retention, sometimes leading to the occurrence of certain defects of cheese, such as a greater friability of curds [28].

For each test, we mark the fermentation time $(\mathrm{pH}$ reaches 4.45) and acidity in this $\mathrm{pH}$. Milk $\mathrm{pH}$ was analyzed at $20{ }^{\circ} \mathrm{C}$ using a pH meter (PHM61; Radiometer, Copenhagen, Denmark).

The fermented milk undergoes an agitation with low speed before switching to the separation curdwhey, which takes place in the same conditions and parameters. For each test in this study, three samples of the curd are taken. In each sample, we measure protein content and the dynamic viscosity that was measured at $10{ }^{\circ} \mathrm{C}$ and under a constant shear rate by a rotational viscometer: Mark Rheolab, it is a rotational rheometer which works according to the couette viscometer principe, when the fluid occupies the space between two coaxial cylinders.

In the Gerber method for measuring fat content, milk fat is separated from proteins by adding sulfuric acid. The separation is facilitated by using amyl alcohol and centrifugation. The fat content is read directly via a special calibrated butyrometer.

\subsection{Statistical Data Analysis}

The study aims to determine the impact of $\mathrm{Xi}$ factors (the composition of raw milk and the conduct of manufacturing of curd) on texture and composition (The $\mathrm{Yi}$ responses). To simplify the statistical analysis, $\mathrm{Xi}$ rating is assigned for factors and $\mathrm{Yi}$ for responses (Table 1).

\section{Table 1. List of variables and abbreviations}

\begin{tabular}{|c|c|}
\hline Variables & Abbreviations \\
\hline \multicolumn{2}{|l|}{ Raw milk: } \\
\hline Protein content ( g/kg ) & $\mathrm{X} 1$ \\
\hline Freezing Point & $\mathrm{X} 2$ \\
\hline \multicolumn{2}{|l|}{ Skim Milk : } \\
\hline Fat $(\mathrm{g} / \mathrm{kg})$ & $\mathrm{X} 3$ \\
\hline Protein content (g/kg) & $\mathrm{X} 4$ \\
\hline Freezing Point & X5 \\
\hline \multicolumn{2}{|l|}{ Characteristics of curd: } \\
\hline Protein content ( g/kg ) & Y1 \\
\hline dynamic viscosity ( Pa.s ) & $\mathrm{Y} 2$ \\
\hline
\end{tabular}

A 5\% significance level was used for the statistical analyses data; the aim is to establish links between variables, to select the physicochemical parameters, which have an impact on the characteristics of the curd. The analysis of the results is ensured by a statistical software MINITAB professional data (16.1.0.0 version). The relevance of the analysis phase is directly related to the quality of the measurements. The responses Yi take the form of an equation: $Y i=f(X 1, X 2, \ldots \ldots ., X n)$. 


\section{RESULTS}

\subsection{Characteristics of raw milk}

The fat content ranges from 34.8 to $37.8 \mathrm{~g} / \mathrm{kg}$ ( average $36.5 \mathrm{~g} / \mathrm{kg}$ ), the protein content ranges from 30.9 to 32.8 $\mathrm{g} / \mathrm{kg}$ (average $31.6 \mathrm{~g} / \mathrm{kg}$ ), the freezing temperature ranges between $-0,498{ }^{\circ} \mathrm{C}$ and $-0,526{ }^{\circ} \mathrm{C}$ (average of $-0,521{ }^{\circ} \mathrm{C}$ ) and the milk $\mathrm{pH}$ varies between 6.65 and 6.76 . The raw milk undergoes the separation of the cream to obtain the skim milk whose fat content does not exceed $0.5 \mathrm{~g} / \mathrm{kg}$. The skimming operations are performed by the same separator, under the parameters control.

\subsection{Characteristics of cheese}

The fermentation is carried out by lactic bacteria, with a dose of rennet. When the $\mathrm{pH}$ of the fermented milk is 4.45 , we proceed by decurdling; the fermentation time for the thirty tests varies between 13 and 16 hours. The curd separation is done by a centrifugal separator, texture and protein content of curd are driven by the curd input flow to the separator. The samples of our tests are taken by the same input flow.

The three samples of the curd were taken in the same curd input flow separation. The protein and the solids content analysis have been carried out by the same reference methods and the same experimental device. For each test, we measure a viscosity of the three samples, we note the average value. All tests are carried out at the temperature of $10{ }^{\circ} \mathrm{C}$. The tests are performed in a period of four months; the results are summarized in the Table 2.

Table 2. Composition and characteristics of raw milk, skim milk and curd $(n=30)$

\begin{tabular}{|c|c|c|c|c|}
\hline & Average & minimum & maximum & SD \\
\hline \multicolumn{5}{|l|}{ Raw Milk: } \\
\hline Protein content $(\mathrm{g} / \mathrm{kg})$ & 31,6 & 30,9 & 32,8 & 0,43 \\
\hline Freezing point $\left({ }^{\circ} \mathrm{C}\right)$ & $-0,521$ & $-0,526$ & $-0,512$ & 0,003 \\
\hline \multicolumn{5}{|l|}{ Skim Mlik: } \\
\hline Fat $(\mathrm{g} / \mathrm{kg})$ & 0,3 & 0 & 0,5 & 0,17 \\
\hline Protein content $(\mathrm{g} / \mathrm{kg})$ & 31,7 & 28,8 & 33 & 0,91 \\
\hline Freezing point & $-0,514$ & $-0,519$ & $-0,506$ & 0,003 \\
\hline \multicolumn{5}{|l|}{ Fermentation: } \\
\hline Fermentation time(hours) & 14,67 & 13 & 16 & 0,8 \\
\hline Acidity of curd at $\mathrm{pH}=4,45$ & 53,5 & 51 & 56 & 1,25 \\
\hline \multicolumn{5}{|l|}{ Characteristics of curd: } \\
\hline Protein content $(\mathrm{g} / \mathrm{kg})$ & 93,06 & 81,34 & 96,98 & 2,8 \\
\hline Dynamic viscosity (Pa.s) & 2976 & 2245 & 3281 & 177,2 \\
\hline
\end{tabular}

SD: standard deviation, Fermentation time: the time that the curd $\mathrm{pH}=4,45$ (casein isoelectric point), Dynamic viscosity in $10^{\circ} \mathrm{C}$. ANOVA $(\mathrm{p}<0.05)$

\section{DISCUSSIONS}

\subsection{The effect of the freezing point of raw milk on the protein content of the curd}

According to the literature, depression of the milk freezing point was often related to an increase in protein and solids content as well as to a decrease in the lactose percent in milk [29-30-31].

The bivariate statistical analysis, using simple linear regression showed that the protein content of the curd is related to the freezing point of the raw milk $(\mathrm{P}-$ value $=$ $0,05, \mathrm{R}^{2}$ adjusted $=64 \%$ ); the values of freezing points are given in ${ }^{\circ} \mathrm{C}$; the figure 1 shows a strong positive correlation between the freezing point of raw milk and the protein content of the curd, obtained by a fermentation of skimmed milk; the simple linear regression showed a strong correlation between the freezing point of raw milk X2 and skimmed milk X5 (P- value $=0,05$, $\mathrm{R}^{2}$ adjusted $=95 \%$ ).

It is known that the increase of the protein content of the raw milk means an increasing rate of total solids (TS), assuming that the rate of the other milk components remains constant. The freezing point significantly varies from the rate of total solids, which can be used as wetting index. Brzozowski and Zdziarski found that decreasing MFP was associated with an increase in protein $(\mathrm{r}=-0.165)$ and fat $(\mathrm{r}=-0.113)$ content [32], by cons we can't conclude that the freezing point of raw milk is correlated with raw milk protein content $(\mathrm{P}=$ 0.057 and $\mathrm{r}=0,103$ ).

From these results, we can say that the freezing point of the raw milk is not only dependent on the total solids content or the milk protein content, but also on the structure and the distribution of casein micelles in suspension. The strong correlation between the protein content of the curd and freezing point of the raw milk can be argued by the fact that the freezing temperature of raw milk is seen as it is affected by the quality and the distribution of casein micelles and colloidal chain of proteins in milk serum.

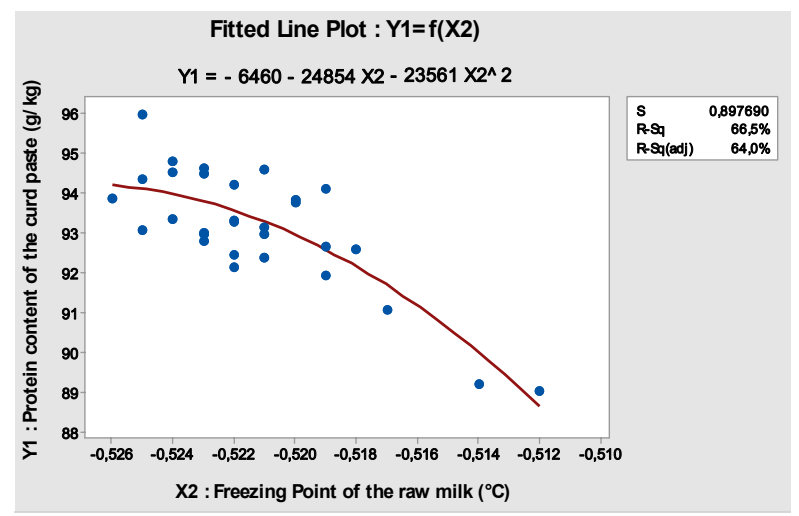

Fig 1: Fitted line plot of the protein content of the curd according to the raw milk freezing point $(p<0.05)$

The osmotic pressure, and hence the freezing point of milk is dependent on the concentration of watersoluble constituents (mainly the proteins). The addition of a solute to any solvent depresses the freezing point. The mathematical relationship between the freezing point depression and concentration of solute was worked out by Raoult [33].

The curd gel is made mainly by micellar combinations of proteins (casein) as well as residual sugar (lactose). This latter is necessary for the growing of ferment that is used as a source of energy.

The lactic acid bacteria (Streptococcus thermophilus, Lactobacillus bulgaricus ) transform milk sugar (lactose) to lactic acid to make cheeses and yagourt, lowering the $\mathrm{pH}$ of the milk that causes a precipitation of micelles casein, when their electric charge becomes null, which happened at their isoelectric point $(\mathrm{pI})$ in $\mathrm{pH}$ between $4-4.5$. Some interactions happened during the lowering of the $\mathrm{pH}$ were responsible for the appearance 
of flocs, which in return interacts to form a soft and brittle gel that tends to exhibit a serum expulsion to the surface [34].

Only about $15 \%$ of the lactose of milk is consumed during fermentation. Its participation in cheese texture is negligible, but as a very small hydrophilic molecule. It contributes to water retention capacity of the gel by providing sufficient space between the protein chains (role «plasticizer»), and a rate of residual fat. The correlation between the protein content of the curd with a freezing point of the raw milk was justified by the fact that proteins are the main milk solids.

\subsection{The effect of the freezing point of raw milk on the viscosity of the curd}

The Freezing Point is the temperature at which a solvent or solution will turn from liquid to solid. More accurately, it is the temperature at which an infinitesimal amount of the solid phase will exist in equilibrium with the liquid phase.

The adjusted $\mathrm{R}^{2}$ (coefficient of determination) between the dynamic viscosity of the curd and freezing point of raw milk reached $65 \%, \mathrm{p}$-value $=0$, (Figure 2); which means that we can have a rheological quality prediction in terms of dynamic viscosity of the curd.

We have already seen that the proteins form the colloidal phase. They are frequently in the form of micelles which are heterogeneous aggregates. These micelles are formed by polymers in the form of complexes with different caseins fractions associated with several minerals, whose most important representative is calcium phosphate. The shape of micelles is subspherical: their average diameter between 30 and $300 \mu \mathrm{m}$, it varies with the species, breed and stage of lactation and it is between 80 and $100 \mu \mathrm{m}$ for cow's milk, the composition of the micelle from a single dairy female is not constant. The amount of $\mathrm{K}$-casein is doubled in small micelles than the large ones and their degree of hydration is higher.

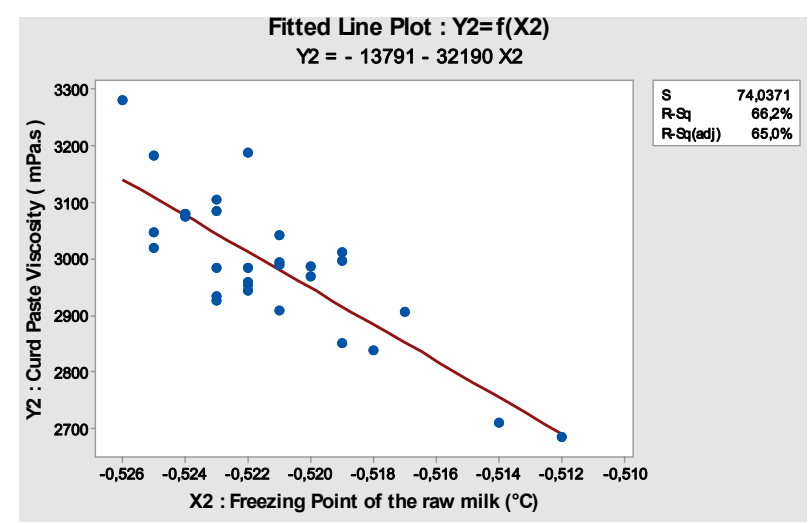

Fig 2: Fitted line plot of the dynamic viscosity as a function of the raw milk freezing point $(p<0.05)$

The structure of the micelles is not totally determined. Many models have been proposed in recent years, the latest puts K-casein at the articulation points of a network composed of casein polymers. The cracks of the protein network are found fixed to colloidal phosphate. This micelle contains $97 \%$ of the total casein, $3 \%$ being a very dispersed state in the aqueous phase.
A remarkable property of calcium phosphocaseinate micelles is their high stability against thermal and mechanical treatments, therefore, the colloidal resists the transformation operations, when moderate temperature variations have taken place. Several factors contribute to provide micelle stability. The basic ones are: electric charge, degree of hydration and mineral load.

The combination of casein micelles during coagulation requires a balance between protein interactions, on the one hand, between protein and solvent, on the other hand, between the repulsive forces and the adjacent polypeptide chains. Strength, flexibility, geometry of the matrix and the rheological behavior of the gel depend on the nature of the involved interactions [35]. Protein stability plays a crucial role in the coagulation of milk, which goes through physicochemical (acidifycation and rennet) and thermal changes (pasteurization). The milk with poor stability leads to some quality problems, such as curd rheology, time fermentation and cheese yield. This stability is illustrated by the rigidity of the micelle of casein, size and colloidal distribution. The influence of these factors on the freezing point allows us to justify the strong correlation between curd viscosity and freezing point of raw milk.

\subsection{Effect of the protein content of skim milk on the protein content of the curd}

A strong correlation between the protein content of the skimmed milk and the curd was observed $\left(\mathrm{R}^{2}\right.$ adjusted (coefficient of determination) $=67,2 \%$ with $\mathrm{P}=0$ ), this value given on figure 3 shows a strong correlation.

The fabrication process of the curd goes through two stages. The first one is the mixed coagulation, the second one is the curd whey separation. These stages have the same process conditions for all the tests.

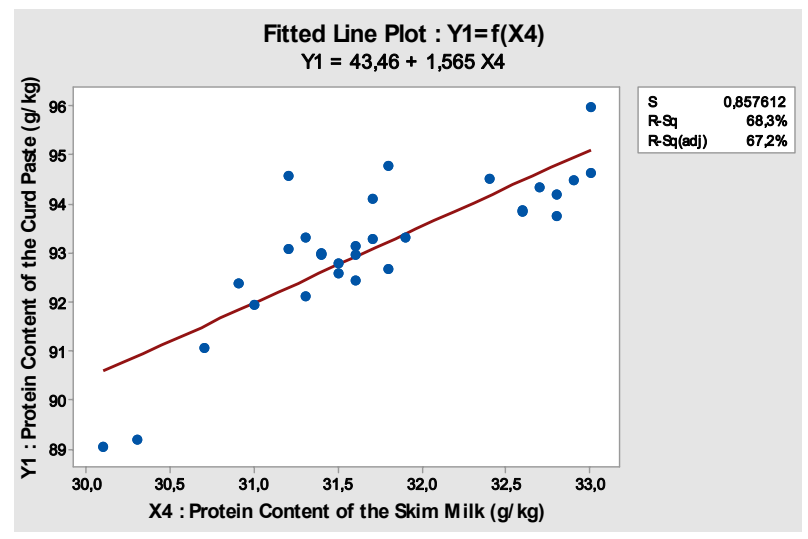

Fig 3: Fitted line plot of the protein content of the curd with protein content of skim milk $(p<0.05)$.

\subsection{The effect of the protein content of skim milk on the viscosity of the curd}

Viscosity was mostly linked to protein content even at high concentrations [1]. Increasing the solids content of cow's milk beyond $9 \%$ improves the gel strength and the viscosity of the curd. This enrichment contribution in dry substance to the curd texture is mainly due to the increase of protein interactions formed during the cross linking of the gel. Furthermore, several studies concluded that the 
amount and types of milk proteins could change the perceived texture of yoghurts [1-36-37-38-39]. The variability of the protein content of skimmed milk is not involved in a meaningful way in the variability of the dynamic viscosity of the curd. This conclusion is justified by the average correlation between $\mathrm{Y} 2$ and $\mathrm{X} 4\left(\mathrm{R}^{2}\right.$ adjusted $=34.5 \%, P=0$ ), shown on figure 4 .

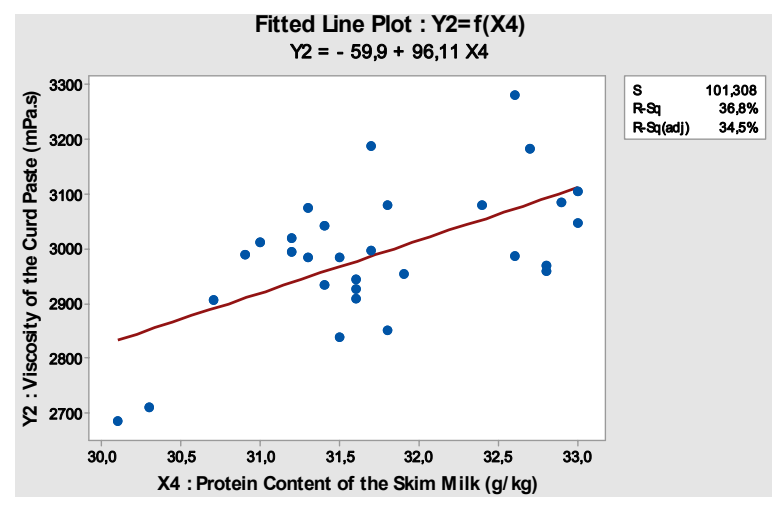

Fig 4: Fitted line plot of dynamic viscosity of curd depending on protein content of skim milk $(p<0.05)$.

\subsection{Descriptive model of the curd viscosity accor- ding to the raw milk freezing point}

To define the freezing point variability according to the parameters of the raw and skimmed milk, a multiple linear regression was performed using Minitab; the aim is to validate a prediction model. The model obtained is:

$$
\mathrm{Y} 2=-13791-32190 \mathrm{X} 2-\mathrm{R}^{2} \mathrm{adj}=65,04 \%
$$

A residual plot graph (figure 5) is used to examine the goodness-of-fit in regression and ANOVA. Examining residual plots helps to determine whether the ordinary least squares assumptions are met. If these assumptions are satisfied, then ordinary least squares regression will produce unbiased coefficient estimates with the minimum variance.

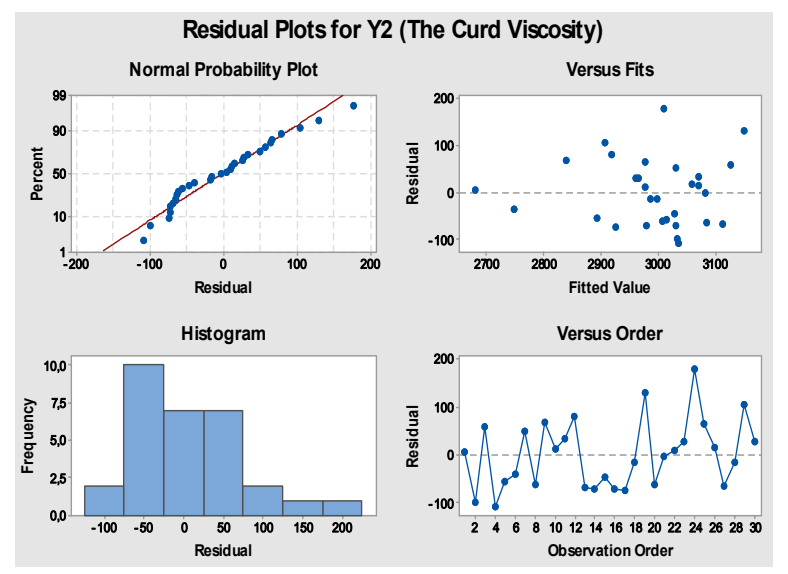

Fig 5: Residual plot of the curd dynamic viscosity $(p<0.05)$

The normal plot of residuals showed that the residuals are normally distributed. The residuals versus fits plot show that the residuals have a constant variance (a random pattern of residuals on both sides of 0 ). The same residuals versus order plot indicate that the residuals are uncorrelated with each other.

We use the Durbin-Watson statistic to perform the test for the presence of autocorrelation in the errors of a regression model [40]. Autocorrelation means that the errors of adjacent observations are correlated. If the errors are correlated, then last squares regression can underestimate the standard error of the coefficients. Underestimated standard errors can make your predictors seem to be significant when they are not [41].

The Durbin-Watson statistic (d) determines whether or not the correlation between adjacent error terms is zero, to get a conclusion from the test, we compare the displayed value for the Durbin-Watson statistic with the correct lower and upper bounds in the famous table of Critical Values of the Durbin-Watson Statistic [41]. If $\mathrm{d}$ $>\mathrm{dU}$, no correlation exists [40], The significance level for the test is 0.05 .

For our study, we choose $\alpha=0.05$ (Significance level), one regressor $\mathrm{k}=1$ and sample size $\mathrm{n}=30$, then the table gives critical values as $[\mathrm{dL}=1.35 ; \mathrm{dU}=1.49]$.

The value given by Minitab is $\mathrm{d}=1.82>\mathrm{dU}=1.49$, we retain $\mathrm{H} 0$ and conclude that no correlation exists.

\section{CONCLUSION}

The objective of this study was to investigate the effect of the freezing point of the raw and skimmed milk on the rheology and protein content of the curd obtained by mixed acid-rennet coagulation.

The results obtained in this study show a significant correlation between the freezing point of the raw milk and the viscosity of the curd, knowing that the fermentation of skim milk and the curd-whey separation are per-formed under the same conditions. They show that the raw milk freezing point is able to offer us a prediction of the rheological quality of the curd (dynamic visco-sity). The solidification temperature of raw milk was seen so affected by the colloidal distribution of casein micelles.

The freezing temperature of raw milk is the minimum temperature at which the milk flow becomes null, and the milk viscosity becomes maximum. It is a transition point of liquid - solid phases. The objective of our study is to show a correlation between the strength of the raw milk at a cold solidification expressed in the freezing point of the raw milk and the resistance to a shear rate expressed as a dynamic viscosity of the curd.

\section{ACKNOWLEDGMENT}

The author would thank Mohamed Zentar for helping to prepare the English version of the manuscript, Youness Kerfadi is gratefully acknowledged for providing milk samples.

\section{AUTHOR CONTRIBUTIONS}

Conceived and designed the experiments: M.Chaoui. Performed the experiments: A.Bouisfi. Analyzed the data: M.Chaoui, A.Bouisfi. Contributed reagents / mater ials/analysis tools: M.Chaoui.

Wrote the paper: A.bouisfi.

\section{REFERENCES}

[1] Huc, D.: Design of a multi-scale texture study of yoghurts using rheology, and tribology mimicking the eating process and microstructure charac- 
terisation - International Dairy Journal, Vol.61, pp. 126-134, 2016.

[2] R. Aleandri, J. C.: Evaluation of Milk for Cheese Production Based on Milk Characteristics and Formagraph Measures - Journal of Dairy Science Vol.72, No.8, pp.1967-1975, 1989.

[3] Ferrer, M. H.: Rheological Properties of Rennet Gels Containing Milk Protein Concentrates - Journal of Dairy Science, Vol.91, No.3, pp. 959-969, 2008.

[4] Balać I, Čolić K, Milovančević M, Uskoković P, Zrilić M.: Modeling of the matrix porosity influence on the elastic properties of particulate biocomposites - FME Transactions, Vol.40, No.2, pp. 81-86, 2012.

[5] Bourne, M. C.: Food texture and viscosity. New York, NY, USA: Academic Press, 2002.

[6] Grygorczyk, A. L.: Extraction of consumer texture preferences for yogurt: comparison of the preferred attribute elicitation method to conventional profiling - Food Quality and Preference, Vol. 27, pp. 215-222, 2013.

[7] Szczesniak, A. S.: Texture is a sensory property Food Quality and Preference, Vol.13, pp. 215-225, 2002.

[8] Jelen, P. A.S.: Quark manufacturing innovation and their effects on quality, nutritive value and consumer acceptance - Food Technol, Vol.43, No.3, pp. 74-81,1989.

[9] Fragassa C, Berardi L, Balsamini G.: Magnetorheological fluid devices: An advanced solution for active control of the wood manufacturing process. FME Transactions, Vol.44, No.4, pp. 333-339, 2016

[10] Jack, F. P.: Texture of hard cheeses - Trends Food Sci. Technol, pp. 160-164, 1992.

[11]Hort, J.: Developments in the textural and rheological properties of UK Cheddar cheese during ripening - International Dairy Journal, Vol. 11. pp. 475-481, 2001.

[12] Claire Agabriel, J.-B. C.: Variabilité des caractéristiques des fromages saint-nectaire fermiers: relations avec la composition du lait et les conditions de production - Le lait, Vol.79, No.3, pp. 291-302, 1999.

[13] Aguilera, J. M.: Microstructural principles of food Processing and engineering - Food structuring, pp. 185-249, 1999.

[14] Mazerolles, G. D.: Infrared and fluorescence spectroscopy for monitoring protein structure and interaction changes during cheese ripening - Le Lait, Vol.81, pp. 509-527, 2001.

[15] Garel J.P, C. J.: Effet de l'alimentation et de la race des vaches sur fabrication de fromage d'Auvergne de saint-nectaire - INRA Prod Anim, Vol.3, pp.127136,1990 .

[16] Martin, B.: Influence des pratiques d'élevage et de fabrication fromagère sur les caractéristiques du lait et du fromage, Cas du reblochon fermier, thèse de l'école nationale supérieure agronomique de Montpellier, 1993
[17] Verdier I., C. J.: Effect of forage type and cow breed on the characteristics of matured SaintNectaire cheeses - Lait, Vol.75, pp. 523-533, 1995.

[18] Verdier I., C. J.: Effect of forage conservation (hay or silage) and cow breed on the coagulation properties of milk and on the characteristics of ripened cheeses - J. Dairy Res. Vol. 65, pp. 9-21, 1998.

[19]FIL: : Lait : détermination de la teneur en azote Fédération Internationale de laitière Association of Officiel Analytical Chemists, FIL 20B, 1993.

[20] Shipe, W. F.: The Freezing Point of Milk A Review - Journal of Dairy Science, Vol.42, No.11, pp. 1745-1762, 1959.

[21] Carole, L. V. : Fondation de technologie laitière du Québec inc, science et technologie du lait transformation du lait - Presses internationales polytechniques, pp. 28, 2002.

[22] J. A. Lucey., H. S.: Formation and physical properties of acid milk - Food Research Iniernational, Vol. 30, No. 7, pp. 529-542, 1998.

[23] Logan, A. D.: Interactive Effects of Milk Fat Globule and Casein Micelle Size on the Renneting Properties of Milk - Food and Bioprocess Technology, Vol.7, No.11, pp. 3175-3185, 2014.

[24] Roefs., S.: Structure of acid casein gels. A study of gels formed after acidification in the cold, Thesis Wage-ningen, Netherlands, Agricultural University, 1986.

[25] V. Hooydonk AC.M., B. I.-d.: pH-induced physicochemical changes of casein micelles in milk and their effect on renneting. Effect of $\mathrm{pH}$ on renneting of milk Neth - Milk Dairy J. Vol.40, pp. 297-313, 1986.

[26]A. Zamora, A. J.: Effect of fat content and homogenization under conventional or ultrahighpressure conditions on interactions between proteins in rennet curds - J. Dairy Sci, Vol.95, pp. 4796-4803, 2002.

[27] McMahon, D. J.: Enzymic coagulation of casein micelles. - a review J. Dairy Sci., Vol.67, pp.919929, 1984.

[28] Izmiroglu S.: Effets de la pasteurisation sur les interactions entre les protéines de la membrane de globule de gras laitier et les micelles de caséines $d u$ babeure, thèse de la faculté des sciences de l'agriculture et de l'alimentation - Université LAVAL, Québec, 2010.

[29] T. Brouwer.: Calculations concerning the determination of the freezing point depression of milk Neth. Milk Dairy J, Vol. 35, pp. 159-175, 1981.

[30]Brzozowski P., Z. K.: Influence of genotype, age, lactation stage and daily milk performance of Black and White cows on freezing point of milk (in Polish) - Med. Weter, Vol.62, pp. 93-95, 2006.

[31] Kedzierska-Matysek M., L. Z.: The effects of breed and other factors on the composition and freezing point of cow's milk in Poland - Int J. Dairy Technol, Vol.64, pp. 336-342, 2011. 
[32] Brzozowski P., Z. K.: Freezing point of udder-milk in milk-producing cows (in Polish) - Med. Weter, Vol.61, pp. 934-936, 2005.

[33] Raoult, F. M. (1884).: Loi Generale de Congelation des Dissolvants - Ann. Chim. Phys, Vol.2, No.6, pp. 66, 1884.

[34] Famelart M.H, G. F.: Agrégation protéique et propriétés gélifiantes et moussantes des protéines laitières- quoi de neuf sur le plan des connaissances ? Innovation Agronomiques, Vol.13, pp. 117-132, 2011.

[35] Lucey J.A., J. M.: ADSA invited review: perspectives on the basis of the rheology and texture properties of cheese - J. Dairy Sci., Vol.86, pp. 2725-2743, 2003.

[36] Kailasapathy, K.: Effect of partially replacing skim milk powder with whey protein concentrate on the sensory qualities of lactose hydrolysed acidophilus yoghurt - Milchwissenschaft, Vol.53, pp. 385-389, 1998.

[37] Sodini, I. R.: The relative effect of milk base, starter, and process on yogurt texture: a review Critical Reviews in Food Science and Nutrition, Vol.44, pp.113-137, 2004.

[38] Sodini, I. L.: Physical properties and microstructure of yoghurts supplemented with milk protein hydrolysates - International Dairy Journal, Vol.15, pp. 29-35, 2005.

[39] Sonne, A. B.-S.: Improved mapping of in-mouth creaminess of semi-solid dairy products by combining rheology, particle size and tribology data. LWT - Food Science and Technology, Vol.59, pp. 342-347, 2014.

[40] Durbin, J. a.: Testing for serial correlation in least squares regression II - Biometrika, Vol. 38, No.1/2, pp. 159-177, 1951.
[41] Savin, N. E.: The Durbin-Watson test for serial correlation with extreme sample sizes or many regressor - Econometrica, Vol.45, No.8, pp.19891996, 1977.

\section{УТИЦАЈ ТАЧКЕ СМРЗАВАНА СИРОВОГ МЛЕКА НА САДРЖАЈ ПРОТЕИНА \\ И РЕОЛОГИЈУ ГРУШЕВИНЕ ДОБИЈЕНЕ КОМБИНАЦИЈОМ КИСЕЛИНЕ И КОАГУЛАЦИЈОМ СИРИЛА}

\section{А. Боуисфи, М. Шаул}

Више аутора наводи да садржај протеина у сировом млеку побољшава карактеристике грушевине, посебно њену вискозност. Ова идеја открива утицај и других параметара на реологију грушевине. Грушевина је биокомпозит и као таква је главни носилац оптерећења самог биокомпозита чија се почетна механичка својства деградирају присуством порозности матрице.

Циљ рада је да се процени како тачка смрзавања сировог млека утиче на реолошка својства гелова добијених комбинацијом киселине и сирила. Узорци свежег млека су коришћени за извођење 30 експеримената. Узорци су прикупљени у пролећном периоду са шест фарми у региону Гарб у Мароку, а фарме су одабране према техничкој опремљености. Циљ је био да се редукује утицај исхране и расе домаћих животиња и климатских услова.

Тачка смрзавања сировог млека је у значајној корелацији са карактеристикама груше-вине. Налази могу да се користе за оптимизацију контроле млека у циљу добијања грушевине бољег реолошког својства. 